\title{
La comedia central y la destrucción universal de los objetos
}

\section{Carlos Oliva}

Bolívar Echeverría, comp., La americanización de la modernidad. México, UNAM/ERA, 2008. 308 pp.

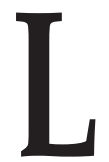

a americanización de la modernidad es un libro sofisticado que reúne a una consolidada vertiente de la academia mexicana and beyond. Se trata, en un esfuerzo por sistematizar el estudio multifacético de la crisis civilizatoria, del estudio de la más poderosa identidad histórica que haya servido a la modernidad capitalista: el americanismo.

El trabajo muestra, en conjunto, algunas de las falacias de la llamada investigación interdisciplinaria, por ejemplo, la meta utópica de la creación de nuevas disciplinas a partir de un cruce metodológico y epistémico que nos haga perder las identidades tradicionales del conocimiento. Lejos de la dispersión cognoscitiva, este libro nos muestra a una serie de investigadores e investigadoras que trabajan en condiciones muy similares a sus pares mundiales, que cuentan con herramientas heurísticas y epistemológicas decantadas y que se mueven en las vías rápidas del conocimiento. Vemos, en este sentido, que sus asertos interdisciplinarios son muy controlados y entre las humanidades y las ciencias casi nulos, si no es que anecdóticos. Vemos aquí, precisamente, un dato de modernidad americana: los distintos saberes son inconmensurables, ya sea por sus montajes idiomáticos, sus formas de prueba y experimentación, sus estrategias de producción y reproducción o, el dato más importante, por su aplicación tecnológica. Un artículo como el de Carlos Monsiváis no puede ser entendido a cabalidad fuera del español, mientras que por el otro lado, Manuel Peimbert habla del sin sentido de no publicar el trabajo de investigación en inglés. Así, el libro muestra, de forma paradójica, a la americanización filtrada, de hecho apuntalando los intentos críticos de esa propia americanización.

Por otra parte, la interdisciplina entre las propias áreas muestra otra faceta. Podríamos decir que en el acotado contexto de cada área universitaria se puede congeniar. Así, los trabajos donde la filosofía se coliga con la política, la teoría de la cultura, la literatura, el feminismo y las teorías del arte, muestran avances destacados. Lo mismo sucede con los cruces entre economía e historia, 
entre historia del arte y filosofía o entre ciencia y política, véase al respecto los textos de Raquel Serur, Rolando Cordera, Manuel Peimbert, Jorge Juanes, Roberto Castro, Pérez Gay y Marta Lamas para mencionar los más importantes ejercicios transdisciplinarios.

El poliedro del libro muestra, en síntesis, las aporías, dubitaciones, contradicciones, pequeñas fugas, militancias y rebeliones que implica pensar en el siglo XXI dentro de un "esquema civilizatorio" que está determinando la misma academia. A la par, si cada trabajo es tomado de manera individual, el libro muestra la irrealidad de cada texto en referencia a algún otro o a varios de los textos del mismo libro y de ahí -sólo un paso- la inverosimilitud de lo escrito frente a ese eufemismo en épocas del capital llamado el "mundo de la vida". Se ilumina, entonces, de manera positiva, la tensión utópica que mantiene la teoría frente a la crisis actual; visto de manera negativa, trasluce el exilio radical de la academia, incluso la academia crítica, frente a la vida pública... vida pública que incluye a la misma universidad.

Quisiera englobar en tres apartados las formas en que los autores y autoras reunidas refieren y desarrollan el problema del americanismo.

Quizá la postura más sostenida en el libro es aquella que no tiene interés en pensar el problema de la americanización. Esto se debe a lo avasallante del propio proceso, a la mimetización radical que guardan todas las sociedades globalizadas con el fenómeno de americanización o a una honesta filiación con los procesos de progreso técnico que encarna la sociedad estadounidense. Esta postura puede incluso darse en un mismo texto que ha criticado, estructuralmente, al propia americanismo. (Debo de confesar que al leer el texto de Monsiváis y enterarme de las virtudes que producen las nuevas series trasmitidas por cable a las que hace referencia, pensé en ir a ver a algún proveedor antes de escribir este texto.) Este abordaje que hacen la mayoría de los autores o autoras convocadas, ya sea encontrando las virtudes del inglés, de la metadifusión de la cultura, de la historia patria de Estados Unidos, de sus sistemas institucionales de investigación, de sus albricias económicas o de sus revoluciones artísticas, tiene la virtud de hacerlos y hacerlas volver la vista hacia los estudios de caso y colocarlos en comparación con un contexto propio, en la mayoría de los casos, con el tema del progreso y la funcionalidad y reificación tecnológica en México. Se trata, podríamos decir, de una crítica ilustrada que no duda, en el fondo, ni de la ciencia, ni de la corrección humanista.

El segundo abordaje es más complejo y se da, en general, a partir de una postura crítica e ilustrada que, sin ser catastrófica, quiere señalar los puntos críticos de enajenación y destacar los procesos de emancipación y desenajenación en la actualización del americanismo, ya sea fuera o dentro de Estados Unidos. Así, las rupturas económicas con un sistema atávico y estructuralmente corrupto, como el mexicano; el impulso de la ciencia; la revalorización de 
la industria cinematográfica, el arte pop o el idioma inglés como vehículo fulgente tanto de ficción como de denuncia. En este sentido, es que se puede sostener que pese a los orígenes "enajenados" de Tin Tán, él acaba siendo no sólo el primer mexicano del siglo XXI, sino algo poco común: un feliz americano que fracasó.

Esta idea de la desenajenación puede verse en la referencia que ya hacía D. H. Lawrence sobre uno de los íconos de Estados Unidos y del americanismo. Dice Lawrence: "Poe no tiene trato con indios o la naturaleza [...] él está absolutamente ocupado en el proceso de desintegración de su propia psique. Como hemos dicho, el ritmo de la actividad artística americana es dual; por un lado, la desintegración y el abandono de la vieja conciencia; por el otro, la formación de la nueva conciencia que emerge. Poe participa sólo de la desintegración". En los textos sobre el americanismo o sobre los aspectos populares de la cultura sajona que abordan los autores y autoras, lo que vemos es que ambas vías, la cándida o pueril de creer que se puede generar una nueva conciencia y la formal o sublime que reconoce centralmente el proceso de destrucción, esconden procesos formales de emancipación, negaciones determinadas del propio sistema que sustancian la valorización del valor, que generan la permanencia iconoclasta del capital.

El tercer enfoque está sostenido casi en solitario por el compilador del texto y coordinador del seminario sobre las versiones de la modernidad. Muchos de los autores y autoras acompañan algunas reflexiones que seguramente Bolívar Echeverría habrá alcanzado en el propio proceso del seminario, pero finalmente se inscriben en los anteriores apartados. Otros, pienso en algunas partes del texto de Monsiváis, por ejemplo, son más radicales que el propio Echeverría, pero, de súbito, apelan a una conciencia de la facticidad y hacen parada para mirar el entorno.

Al leer el texto de Echeverría, recordé que un día en Ciudad Juárez, al lado de la barda fronteriza, un poeta me dijo: "te voy a contar algo que vale mucho y un día me has de pagar. Cuando uno ve los cañones de Estados Unidos entiende un poco a ese mundo... ahí el tiempo crece hacia adentro y perfora la tierra”. Espero que al colocar aquí mi reminiscencia pague y, ojalá, no deba más. El texto de Echeverría, como todo buen marxista, finalmente buen kantiano, procede con base en una serie de síntesis teóricas que le permite iluminar los fenómenos de una forma sustancial sin demérito de la forma. Justo por esta razón, todo lo que he dicho con anterioridad está ya sintetizado por Bolívar Echeverría: la desenajenación como consumo; el republicanismo como modelo de las tecnologías del poder del capital; la vertiente crítica del humanismo subsumido por la valorización; el espontaneísmo de la americanización; todo esto, es el mundo incantatorio de la más ferviente y feroz modernización y estilización del mundo del valor económico y moral que sustenta la pueril civili- 
zación occidental. Al ser sólo forma de otra forma y subsumir realmente todo a un principio de constitución formal, convierte al mundo, como también lo han visto los modernos, en una única comedia. Una comedia en la que para participar hay que destruir en cada objeto, un objeto universal. 